\title{
Phylogenetic characterization of the bacterium-like organism associated with marginal chlorosis of strawberry and proposition of a Candidatus taxon for the organism, " Candidatus Phlomobacter fragariae'
}

\author{
Leyla Zreik, Joseph M. Bové and Monique Garnier
}

Laboratoire de Biologie Cellulaire et Moléculaire, Institut National de la Recherche Agronomique, et Université Victor Ségalen Bordeaux 2, 33883, BP 81, Villenave d'Ornon cedex, France Author for correspondence: Monique Garnier. Tel: +33 556843149. Fax : + 33556843159 .
e-mail: garnier@ bordeaux.inra.fr
Marginal chlorosis is a new disease of strawberry which was first seen in France in 1988. A phloem-restricted bacterium-like organism was found associated with the disease. Even though the organism could not be cultured, and resembles in this way most other phloem-restricted pathogens, characterization was achieved from the sequence of its PCR-generated 165 rDNA, and comparison with other organisms. From these studies, the strawberry agent was found to be a new bacterium within group 3 of the gamma subclass of Proteobacteria, a group of Gram-negative bacteria including, in particular, insect symbionts or parasites as well as enterobacteria. Its closest relative, Arsenophonus nasoniae, is the causal agent of the sonkiller trait in wasps. The two bacteria share $92 \% 165$ rDNA sequence identity. We propose a Candidatus taxon for the marginal-chlorosis-associated bacterium, ' Candidatus Phlomobacter fragariae'.

Keywords: 'Candidatus Phlomobacter fragariae', marginal chlorosis of strawberry

\section{INTRODUCTION}

Marginal chlorosis is a new disease of strawberry (Fragaria $\times$ ananassa) which was first seen in France in 1988. Electron microscopy of affected strawberry plants revealed the presence of a walled bacterium-like organism (BLO) found to be restricted to the sieve tubes within the phloem tissue (14). Attempts to grow the BLO in artificial media were unsuccessful. This is not too surprising as most phloem-restricted pathogens such as the wall-less phytoplasmas $(1,12)$ and the walled liberobacters $(1,6)$ have also resisted in vitro cultivation. Trials to transmit the strawberry BLO, by dodder, to periwinkle plants (Catharantus roseus), the most common experimental host for phloem-restricted pathogens, were also unsuccessful. To compare the strawberry-associated bacterium to the citrus huang-

Abbreviations: BLO, bacterium-like organism; RDP, Ribosomal Database Project.

The GenBank accession number for the marginal-chlorosis-associated BLO 165 rDNA sequence reported in this paper is U91515. longbing (greening) liberobacters (9), the only two phloem-restricted bacterial species that have been characterized so far, the serological (5) and molecular reagents $(10,17)$ specific for ' Candidatus Liberobacter asiaticum' and 'Candidatus Liberobacter africanum' were applied to the BLO-infected strawberry plants. These reagents failed to react, indicating that the citrus-liberobacters and the strawberry-associated BLO were different organisms.

To determine the phylogenetic position of the marginal chlorosis BLO, we PCR-amplified, cloned and sequenced its $16 \mathrm{~S}$ rDNA. Comparisons with sequences of $16 \mathrm{~S}$ rDNAs obtained from the GenBank database revealed that the marginal chlorosis BLO was a new genus in group 3 of the gamma subclass of Proteobacteria $(20)$.

\section{METHODS}

Plant material. Healthy strawberry plants were from in vitro propagations. Symptomless and marginal chlorosis affected plants were collected in strawberry fields in south-western 
France, Dordogne and Lot et Garonne regions. The plants were maintained in the greenhouse at $20^{\circ} \mathrm{C}$. The presence of the BLO in affected plants was ascertained by electron microscopy. Phytoplasmas can occasionally infect strawberry plants (14). The plant material used in this work was free of phytoplasmas as only negative PCR reactions were obtained with universal primers for amplification of phytoplasmas $16 \mathrm{~S}$ rDNA $(11,18)$ and no phytoplasmas were seen by electron microscopy.

Extraction of DNA from plants. Crude nucleic acids were extracted from strawberry plants as described by Gawel \& Jarret (7).

PCR amplification of 16S rDNA. Aliquots of approximately 20 ng DNA from healthy or infected strawberry plants were amplified with the universal primers $\mathrm{fd} 1 / \mathrm{rpl}$ for amplification of prokaryotic 16S rDNA (18). Amplification was performed in $50 \mu \mathrm{l}$ reaction mixtures containing the dNTPs each at a concentration of $125 \mu \mathrm{m}$, the primers at a concentration of $0.5 \mu \mathrm{M}$ each, and $2.5 \mathrm{U}$ Taq polymerase (Gibco-BRL). The PCR conditions were as follows: 35 cycles consisting of $1 \mathrm{~min}$ at $92^{\circ} \mathrm{C}, 1 \mathrm{~min}$ at $57^{\circ} \mathrm{C}$, and $1 \mathrm{~min}$ at $72{ }^{\circ} \mathrm{C}$, plus an additional cycle of $10 \mathrm{~min}$ at $72^{\circ} \mathrm{C}$ for chain elongation. All amplifications were done in a thermocycler Thermojet (Eurogentec). The amplified DNA was analysed and visualized by electrophoresis on $1 \%$ agarose gels, before and after digestion with restriction enzymes $E c o$ RI and $B c l I$.

DNA cloning and sequencing. PCR-amplified DNA was cloned into plasmid vector pGEM-T (Promega Biotech) according to the manufacturer's instructions. Both strands of the DNA fragment were sequenced using a T7 polymerase kit (Pharmacia).

PCR amplification with primers specific for the amplified DNA. Two primers Fra 4 (5'-CTCCTCTGTCTCTAAAGG$\left.3^{\prime}\right)$ and Fra 5 (5'-AGCAATTGACATTAGCGA-3') specific for the amplified $16 \mathrm{~S}$ rDNA sequence, were synthesized and used for amplification of DNA extracted from healthy and BLO-infected strawberry plants under the following conditions: 35 cycles of $1 \mathrm{~min}$ at $92^{\circ} \mathrm{C}, 1 \mathrm{~min}$ at $52{ }^{\circ} \mathrm{C}$, and $1 \mathrm{~min}$ at $72^{\circ} \mathrm{C}$. Amplified DNA was visualized as above.

Phylogenetic analysis. The $16 \mathrm{~S}$ rDNA sequence of the BLO was compared to those of other bacteria. A phylogenetic tree was constructed using the SUGGEST TREE tool of the Ribosomal Database Project (RDP) (15). The bacteria used in these comparisons and their accession numbers are given in the legend of Fig. 3.

\section{RESULTS}

\section{Amplification of 165 rDNA from healthy or marginal chlorosis-BLO infected strawberry plants}

When DNA extracted from healthy strawberry plants was amplified with universal primers $\mathrm{fdl} / \mathrm{rpl}$, two DNA bands $(1.7$ and $1.5 \mathrm{~kb})$ were observed upon electrophoresis. They correspond very probably to mitochondrial and chloroplastic 16S rDNA as the universal primers are known to amplify plant organelle $16 \mathrm{~S}$ rDNA (18). The same two bands were observed upon amplification of DNA extracted from BLOinfected strawberry plants. After digestion of the amplicons with $B c l$, the same profiles were obtained with DNA amplified from healthy (Fig. 1, lane 1) and infected strawberry plants (Fig. 1, lane 2). However,

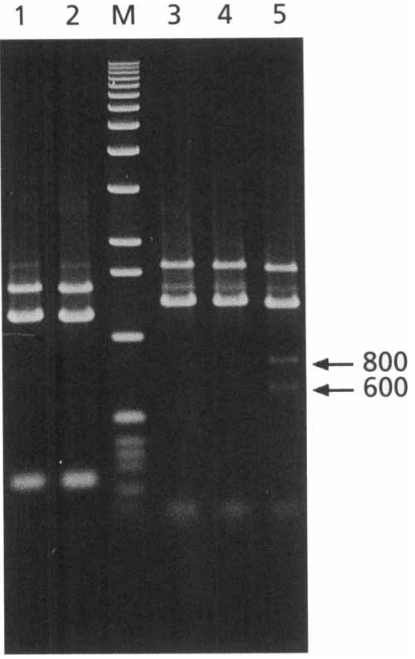

Fig. 1. Agarose gel electrophoresis of DNA amplified by PCR with universal primers for amplification of prokaryotic $16 \mathrm{~S}$ rDNA from healthy (lanes 1, 3 and 4) or BLO-infected (lanes 2 and 5) strawberry plants after digestion with $B C l$ (lanes 1 and 2) or EcoRI (lanes 3, 4 and 5). M, 1 kb ladder (Gibco-BRL).

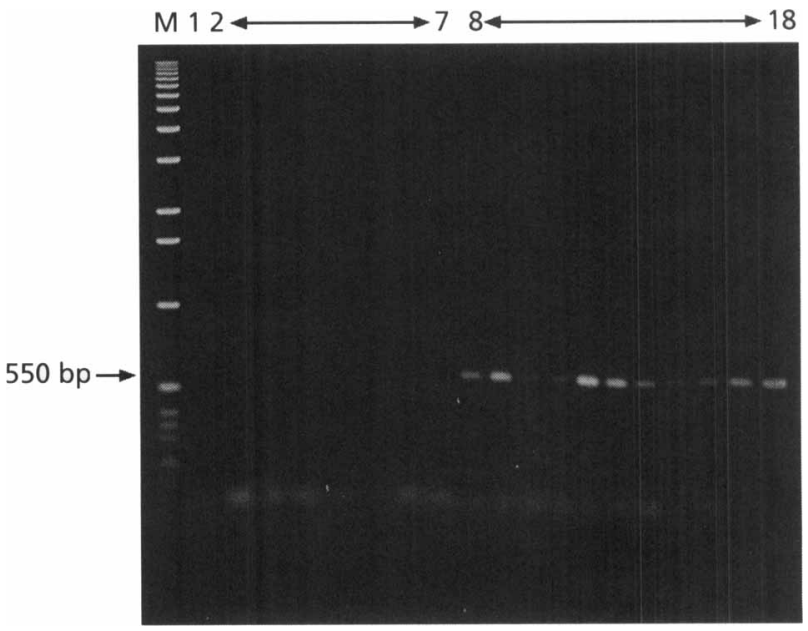

Fig. 2. Agarose gel electrophoresis of DNA amplified by $P C R$ with primers Fra4 and $\mathrm{Fra} 5$ from water (lane 1) or from DNA extracted from healthy (lanes 2-7) or BLO-infected (lanes 8-18) strawberry plants. M, 1 kb ladder (Gibco-BRL).

after digestion with EcoRI, only DNA from infected strawberry plants yielded two additional bands, of about 800 and 600 bp (Fig. 1, lane 5). They were likely to represent the $16 \mathrm{~S}$ rDNA of the BLO. Indeed, it is known that the $16 \mathrm{~S}$ rDNA of most bacteria contain an EcoRI site $(9,18)$. The total DNA amplified from BLO-infected strawberry plants was cloned as described in Methods. Three separate clones containing an $E c o$ RI-sensitive insert were selected and sequenced; the sequences were found identical. Sequence comparisons with the 16S rDNA sequences of other bacteria in GenBank, indicated that the cloned and 


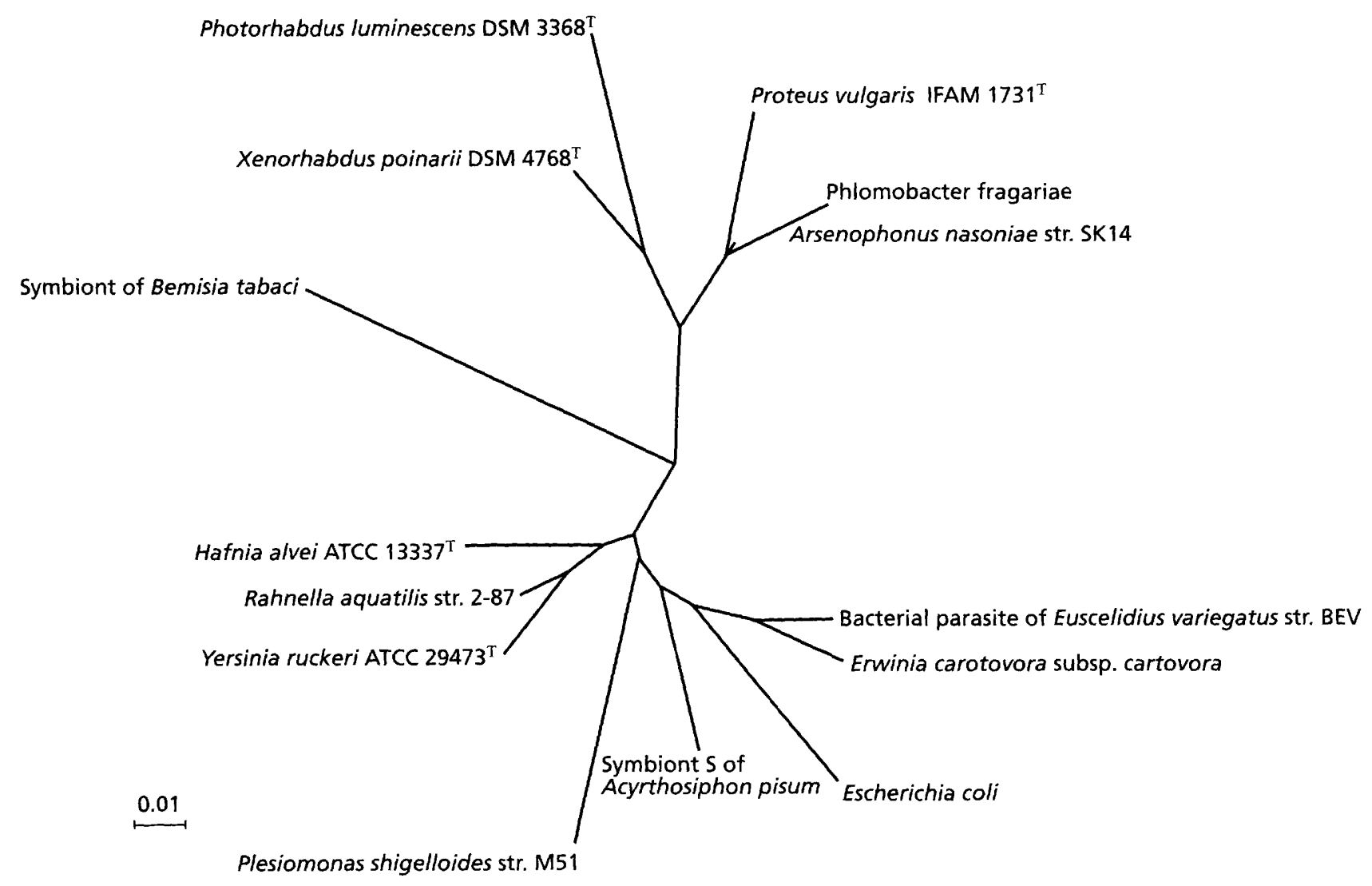

Fig. 3. Phylogenetic tree constructed with the sequences of 165 rDNAs obtained from GenBank. The organisms used in this study were the following: Arsenophonus nasoniae SK14 (M90801), Proteus vulgaris 1731 (X07652), Hafnia alvei 13337 (M59155), Rahnella aquatilis 2-87 (X79937), Yersinia ruckeri 29473 (X75275), Plesiomonas shigelloides M61 (M59159), Acyrthosiphon pisum symbiont S (M27040), Escherichia coli (J01859), parasite of Euscelidius variegatus (Z14096), Erwinia carotovora (M59149), Photorhabdus luminescens 3368 (X82248), Xenorhabdus poinarii 4768 (X82253), and symbiont of Bemisia tabaci (211925). The scale corresponds to $1 \%$ substitution.

sequenced DNA was indeed bacterial $16 \mathrm{~S}$ rDNA. Two oligonucleotides Fra 4 and Fra 5 (see Methods) specific for the new sequence were defined.

\section{The sequenced DNA is the 165 rDNA of the strawberry BLO}

Oligonucleotides Fra 5 and Fra 4 were used respectively as forward and reverse primers for PCR amplifications with DNA extracted from 6 healthy strawberry plants and 11 BLO-infected ones. No amplification was obtained with DNA extracted from healthy plants (Fig. 2, lanes 2-7) while DNA bands of the expected size $(550 \mathrm{bp})$ and of variable intensities were present when DNA from infected strawberry plants was used as target for PCR (Fig. 2, lanes 8-18). The specificity of the primers for the strawberry BLO was further documented by using them in PCR amplifications with DNA extracted from periwinkle plants infected with either one of the two liberobacter species or with the phytoplasmas of Aster Yellows, cabbage chloranty, clover phyllody, apple proliferation, eggplant little leaf, stolbur, Western X (12) or 'Candidatus Phytoplasma aurantifolia' (21); DNA extracted from the following members of the gamma Proteobacteria was also used: Escherichia coli, Xylella fastidiosa and Xanthomonas fragariae. No amplification was obtained with any one of these DNAs (results not shown).

\section{Phylogenetic analysis}

The 16S rDNA sequence of the strawberry bacterium was used to determine its phylogenetic position. As shown on the phylogenetic tree of Fig. 3, the strawberry bacterium (referred to as Phlomobacter fragariae, see below) belongs to group 3 of the gamma subclass of Proteobacteria, and its closest relative in the RDP database was Arsenophonus nasoniae, the recently characterized agent of the son-killer trait in the parasitic wasp Nasonia vitripennis $(8,19)$, with which it shares $92 \%$ 16S rDNA identity. The $16 \mathrm{~S}$ rDNA sequence of the strawberry BLO contains most of the bases signatures of the gamma subclass, except four (positions 760, 878, 1298 and 1460, E. coll numbering). It possesses the oligonucleotide signature AAACUCAAAUG (position 925-935, E. coli num. bering) distinguishing the gamma subclass from the other subclasses of Proteobacteria (20). In addition 
eleven oligonucleotide signatures characteristic of the gamma-3 sub-group, were present in the $16 \mathrm{~S}$ rDNA sequence of the strawberry bacterium.

Compared to the 16S rDNA sequence of the other gamma Proteobacteria including Arsenophonus nasoniae, the 16S rDNA of the strawberry bacterium differs by a relatively large deletion of 36 nucleotides (positions 88-123, E. coli numbering).

\section{DISCUSSION}

Strawberry marginal chlorosis is a serious disease in production fields in South-Western France where the percentage of infection ranges from 1 to $6 \%$ with occasional percentages greater than $20 \%$ in certain locations. Using universal primers for the amplification of prokaryotic 16S rDNA and restriction of the amplified DNA with EcoRI, we were able to clone the $16 \mathrm{~S}$ rDNA of the bacterium associated with the disease. Sequence analysis of the cloned rDNA showed the marginal chlorosis agent to be a new bacterium within group 3 of the gamma subclass of Proteobacteria. In the RDP database, its closest relative is Arsenophonus nasoniae. The two bacteria share $92 \%$ 16S rDNA sequence identity. Arsenophonus nasoniae has been cultured in artificial media (19). Attempts to culture the strawberry bacterium in these media as well as in those used for the culture of BEV (bacterium of Euscelidius variegatus), a bacteria belonging also to the gamma-3 sub-group (16) or in media used for the growth of the phloem-restricted spiroplasmas (2) have failed.

Phloem-restricted, uncultured walled bacteria have been reported to be associated with 21 different diseases but, as of today, only one such bacterium, the citrus huanglongbing (greening) agent has been phylogenetically characterized (9). It belongs to the alpha subclass of the Proteobacteria. Characterization of the strawberry bacterium shows it to be a member of the gamma-3 sub-group. Recently, Bruton et al. (3) found a BLO in watermelon and cantaloupe plants affected by yellow vine disease, in Texas and Oklahoma. This $\mathrm{BLO}$ is also a member of the gamma Proteobacteria (B. D. Bruton, personal communication); however, primers Fra 4 and Fra 5 failed to amplify DNA from BLO-infected watermelons (result not shown), and primers designed from the sequence of the yellow vine bacterium failed to amplify DNA from BLO-infected strawberry plants (B. D. Bruton, personal communication). Thus, the bacteria associated with watermelon in the United States and with strawberry in France are different. These data indicate that at least three different uncultured bacteria occur in the phloem: Liberobacters, the strawberry agent and the watermelon agent.

The alpha and gamma-3 subclass of the Proteobacteria, comprise a large number of insect- and other arthropod-associated bacteria. As phloem-restricted plant pathogens are transmitted by insect vectors, generally leafhoppers or psyllids, it is relevant to notice that these plant agents belong to bacterial groups associated with insects. The insect vector of the strawberry bacterium is yet unknown. Using the sequence of the $16 \mathrm{~S} \mathrm{rDNA}$, a PCR method is presently being developed to detect the bacterium. As we have already shown in this work, primers Fra 4 and Fra 5 are able to detect the bacterium in strawberry plants (Fig. 2). However, we foresee difficulties in the detection of the bacterium in insects as they are known to carry many uncharacterized symbionts and/or parasites, which are likely to be group 3 gamma Proteobacteria. Interference with enterobacteria might also be encountered.

Murray \& Schleifer (13) have suggested to record the properties of putative taxa of uncultured organisms by a 'Candidatus' designation. On the basis of our characterization data, we propose for the strawberry bacterium the designation "Candidatus Phlomobacter fragariae', Phlomobacter from the Greek phloos (bark) and bacter (bacterium). The marginal chlorosis bacterium is thus described as follows: 'Candidatus Phlomobacter fragariae' [( $\gamma-3$ Proteobacteria $)$ NC; G-F; NAS (GenBank no. U91515), oligonucleotide sequence complementary to unique region of $16 \mathrm{~S}$ rDNA 5'-AGCAATTGACATTAGCGA-3', S (Fragaria $\times$ ananassa, phloem); $\mathrm{M} ;$.

\section{ACKNOWLEDGEMENTS}

This work was supported by grants from CIREF (Centre Interrégional de Recherche et Expérimentation de la Fraise), SNPPF (Syndicat National des Producteurs de Plants de Fraisiers) and DRAF (Regional Agriculture Services). We thank J. G. Nourriseau and J. L. Danet for supplying the plant material used in this work and B. D. Bruton for kindly providing us with DNA extracted from healthy and yellow vine-affected watermelons.

\section{REFERENCES}

1. Bové, J. M. \& Garnier, M. (1997). Walled and wall-less eubacteria from plants: sieve-tube-restricted plant pathogens and plant-surface contaminants. In Pathogen and Microbial Contamination Management in Micropropagation, pp. 45-60. Edited by A. C. Cassells. Dordrecht: Kluwer Academic Publishers.

2. Bové, J. M., Whitcomb, R. F. \& McCoy, R. E. (1983). Culture techniques for spiroplasmas from plants. Methods Mycoplasmol 2, 225-234.

3. Bruton, B. D., Pair, S. D. \& Wann, E. V. (1995). Yellow vine disease of watermelon and Cantaloupe in Texas and Oklahoma. Report of the US Department of Agriculture. Lane, OK: South Central Research Laboratory.

4. Fos, A., Danet, J. L., Zreik, L., Garnier, M. \& Bové, J. M. (1992). Use of a monoclonal antibody to detect the stolbur mycoplasmalike organism in plants and insects and to identify a vector in France. Plant Dis 76, 1092-1096.

5. Gao, S., Garnier, M. \& Bové, J. M. (1993). Production of monoclonal antibodies recognizing most strains of the greening BLO by in vitro immunization with an antigenic protein purified from the BLO. In Proceedings of the 12th 
Conference of the International Organization of Citrus Virologists, pp. 244-249. Edited by P. Moreno, J. V. da Graça \& L. W. Timmer. Riverside, CA : c/o Department of Plant Pathology.

6. Garnier, M. \& Bové, J. M. (1993). Citrus greening disease and the greening bacterium. In Proceedings of the 12 th Conference of the International Organization of Citrus Virologists, pp. 212-219. Edited by P. Moreno, J. V. da Graça \& L. W. Timmer. Riverside, CA: c/o Department of Plant Pathology.

7. Gawel, N. J. \& Jarret, R. L. (1991). A modified CTAB DNA extraction procedure for Musa and ipomea. Plant Mol Biol Rep 9, 262-266.

8. Gherna, R. L., Werren, J. H., Weisburg, W., Cote, R., Woese, C. R., Mandelco, L. \& Brenner, D. J. (1991). Arsenophonus nasoniae gen. nov., sp. nov., the causative agent of the sonkiller trait in the parasitic wasp Nasonia vitripennis. Int $J$ Syst Bacteriol 41, 563-565.

9. Jagoueix, S., Bové, J. M. \& Garnier, M. (1994). The phloemlimited bacterium of greening disease of citrus is a member of the $\alpha$ subdivision of the proteobacteria. Int $J$ Syst Bacteriol 44, 379-386.

10. Jagoueix, S., Bové, J. M. \& Garnier, M. (1996). PCR detection of the two liberobacter species associated with greening disease of citrus. Mol Cell Probes 10, 43-50.

11. Kirkpatrick, B. C., Smart, C. D., Blomquist, C., Gurra, L., Harrisson, N., Ahrens, U., Lorentz, K. H., Schneider, B. \& Seemüller, E. (1994). Identification of MLO strains specific PCR primers obtained from 16/23S rRNA spacer sequences. IOM Lett 3, 261-262.

12. McCoy, R. E., Caudwell, A., Chang, C. J. \& 16 other authors (1989). Plant diseases associated with mycoplasma-like organisms. In The Mycoplasmas, vol. 5, Spiroplasmas, Acholeplasmas, and Mycoplasmas of Plants and Arthropods, pp. 545-640. Edited by R. F. Whitcomb \& J. G. Tully. New York: Academic Press.

13. Murray, R. G. E., \& Schleifer, K. H. (1994). Taxonomic notes: a proposal for recording the properties of putative taxa of procaryotes. Int J Syst Bacteriol 44, 174-176.

14. Nourrisseau, J. G., Lansac, M. \& Garnier, M. (1993). Marginal chlorosis, a new disease of strawberries associated with a bacteriumlike organism. Plant Dis 77, 1055-1059.

15. Olsen, G. J., Larsen, N. \& Woese, C. R. (1991). The ribosomal RNA Database Project. Nucleic Acids Res 19, 2017-2021.

16. Purcell, A. H., Steiner, T., Mégraud, F. \& Bové, J. M. (1986). In vitro isolation of a transovarially transmitted bacterium from the leafhopper Euscelidius variegatus (Hemiptera: Cicadellidae). J Invertebr Pathol 48, 66-73.

17. Villechanoux, S., Garnier, M., Renaudin, J. \& Bové, J. M. (1992). Detection of several strains of the bacterium-like organism of citrus greening disease by DNA probes. Curr Microbiol 24, 89-95.

18. Weisburg, W. G., Barns, S. M., Pelletier, D. A. \& Lane, D. J. (1991). 16S ribosomal DNA amplification for phylogenetic study. J Bacteriol 173, 697-703.

19. Werren, J. H., Skinner, S. W. \& Huger, A. (1986). Male-killing bacteria in a parasitic wasp. Science 231, 990-992.

20. Woese, C. R., Weisburg, W. G., Hahn, C. M., Paster, B. J., Zablen, L. B., Lewis, B. J., Macke, T. J., Ludwig, W. \& Stackebrandt, E. (1985). The phylogeny of purple bacteria: the gamma subdivision. Syst Appl Microbiol 6, 25-33.

21. Zreik, L., Carle, P., Bové, J. M. \& Garnier, M. (1995). Characterization of the mycoplasmalike organism associated with witches'-broom disease of lime and proposition of a Candidatus taxon for the organism, 'Candidatus Phytoplasma aurantifolia'. Int $J$ Syst Bacteriol 45, 449-453. 